\title{
Soil Characteristics of University Lands: A Case Study of Five Representative Campuses in Different Regions of China
}

\author{
Yunyue $\mathrm{Du}^{1}$, Jianv $\mathrm{Liu}^{1}$, Yuqing $\mathrm{He}^{1}$, and Mingzhu Wang ${ }^{1}$ \\ ${ }^{1}$ Nankai University
}

February 18, 2022

\begin{abstract}
With the increasing of university, the soil environmental problems caused by extensive campus land use need to be addressed. In China, little related research has been conducted on present soil status of university campuses based on comprehensive index system. In this study, five university campuses in different regions of China were selected as representative, and three different functional areas were sampled at each campus. Basic soil, pollution, and ecological indicators were used in combination to analyze the present status of the tested soils. The results showed that the $\mathrm{pH}$ values were slightly higher than local background values, while the total organic carbon (TOC) content was significantly higher than the background values. The concentrations of typical heavy metals, total petroleum hydrocarbons (TPHs) and polycyclic aromatic hydrocarbons (PAHs) were at safe levels, though $\mathrm{Cd}$ and $\mathrm{Hg}$ concentrations were higher than the background values. The concentration of TPHs was higher at the gates of the university campuses, and the PAHs in surface soils were mainly low in molecular weight. Actinobacteria and Proteobacteria, which play important roles in nitrogen cycling, were the dominant bacteria. Most indicator values differed significantly among the campuses, but not among different functional areas on the same campus. Vegetation cover and TOC were the most strongly correlated with the other indicators. Overall, the soils at the university campuses were not polluted, and the soil characteristics appeared to be well managed. This study provides a reference for the construction, rational use, and protection, of the ecological environments of university campus soils.
\end{abstract}

\section{Hosted file}

cover letter.doc available at https://authorea.com/users/461210/articles/556959-soilcharacteristics-of-university-lands-a-case-study-of-five-representative-campuses-indifferent-regions-of-china

\section{Hosted file}

manuscript.docx available at https://authorea.com/users/461210/articles/556959-soilcharacteristics-of-university-lands-a-case-study-of-five-representative-campuses-indifferent-regions-of-china

\section{Hosted file}

figures.docx available at https://authorea.com/users/461210/articles/556959-soilcharacteristics-of-university-lands-a-case-study-of-five-representative-campuses-indifferent-regions-of-china 